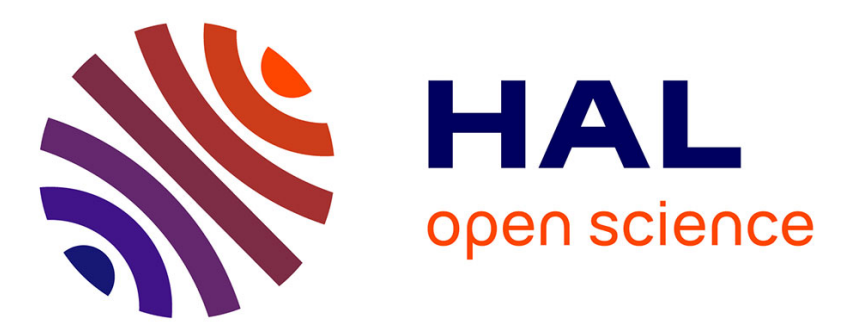

\title{
Dynamics of various viral groups infecting autotrophic plankton in lake Geneva
}

\author{
Ammini Parvathi, Xu Zhong, Stéphan Jacquet
}

\section{To cite this version:}

Ammini Parvathi, Xu Zhong, Stéphan Jacquet. Dynamics of various viral groups infecting autotrophic plankton in lake Geneva. Advances in Oceanography and Limnology, 2012, 3 (2), pp.171-191. hal02641922

\section{HAL Id: hal-02641922 \\ https://hal.inrae.fr/hal-02641922}

Submitted on 28 May 2020

HAL is a multi-disciplinary open access archive for the deposit and dissemination of scientific research documents, whether they are published or not. The documents may come from teaching and research institutions in France or abroad, or from public or private research centers.
L'archive ouverte pluridisciplinaire HAL, est destinée au dépôt et à la diffusion de documents scientifiques de niveau recherche, publiés ou non, émanant des établissements d'enseignement et de recherche français ou étrangers, des laboratoires publics ou privés. 


\title{
Dynamics of various viral groups infecting autotrophic plankton in Lake Geneva
}

\author{
Ammini Parvathi ${ }^{\mathrm{ab}}, \mathrm{Xu}$ Zhong $^{\mathrm{b}}$ and Stéphan Jacquet ${ }^{\mathrm{b} *}$ \\ ${ }^{a}$ National Institute of Oceanography, Dr Salim Ali Road, PO Box 1913, Kochi, 682018 India; \\ INRA, UMR 042 CARRTEL, 75 Avenue de Corzent, 74203 Thonon-les-Bains cx, France
}

(Received 27 August 2012; final version received 4 October 2012)

\begin{abstract}
Viral community structure and dynamics were investigated for the first time in surface waters $(0-20 \mathrm{~m})$ of Lake Geneva over a 5 -month period between July and November 2011. Abundances of autotrophic picoplankton, heterotrophic bacteria and virus-like particles determined using flow cytometry revealed their predominance during the summer months followed by a slight decrease in fall. Two groups of viruses could be discriminated, referred to as virus-like particles (VLP) group 1 and 2. The abundance of VLP1 correlated significantly with the bacterial abundance, while that of VLP2 correlated with both chlorophyll $a$ and picocyanobacterial abundance suggesting a tight coupling between these viral groups and bacteria or phytoplankton. The abundance of cyanomyoviruses and cyanopodoviruses varied between $7.3 \times 10^{2} \mathrm{ml}^{-1}$ (July) to $1.2 \times 10^{4} \mathrm{ml}^{-1}$ (November) and $5.8 \times 10^{3} \mathrm{ml}^{-1}$ (July) to $2.2 \times 10^{4} \mathrm{ml}^{-1}$ (September), respectively. The abundance of the picocyanobacterial hosts was in concurrence with that of the cyanophages, being higher in late summer. Polymerase chain reaction denaturing gradient gel electrophoresis (PCR-DGGE) of viral signature genes such as $g 20, g 23, m c p, p o l B, p s b A$ and $p s b D$ revealed a relatively high richness within these genes with their diversity increasing towards the summer months. The diversity of $p s b D$ was found to be particularly high and correlated with picocyanobacterial abundance suggesting that cyanophages may be directly responsible for a significant proportion of carbon fixation in Lake Geneva.
\end{abstract}

Keywords: virus; cyanophages; algal viruses; PCR-DGGE; PFGE; qPCR

\section{Introduction}

Unicellular picophytoplankton (in particular picocyanobacteria) can be the most abundant primary producers in many aquatic environments [1,2]. Their community structure, functioning, species diversity and succession may be largely influenced by viruses directly through lysis or horizontal gene transfer and indirectly by using available nutrients following viral lysis of bacteria [3-8]. Viruses occur in high abundance in most aquatic systems, their counts ranging from $10^{6}$ to $10^{8} \mathrm{ml}^{-1}$. Viruses of marine cyanobacteria such as Prochlorococcus and Synechococcus have been relatively well studied [9-11] and the marine field has generally received more attention than freshwaters $[12,13]$. Because viruses are mostly species or strain specific [14], viruses are thought to be the most diverse component in aquatic systems but temperate lakes still suffer a lack of data, especially in terms of community structure, richness and diversity $[13,15]$.

*Corresponding author. Email: stephan.jacquet@thonon.inra.fr 
Unlike bacterial diversity investigations, studies on viral diversity are constrained due to the absence of universal genes such as the $16 \mathrm{~S}$ rRNA gene of bacteria and the $18 \mathrm{~S}$ rRNA gene of eukaryotes [16]. Researchers have suggested the use of family specific genes or signature genes to study different groups of viruses [17]. Thus, previous studies have used g20 (T4 portal protein gene 20) [18-21] and $g 23$ genes for the detection of cyanomyoviruses and/or the T4-like myovirus community [22], polA gene for cyanopodoviruses [11], $p s b A$ and $p s b D$ for photosynthetic genes in cyanophages [23-25] and polB or $m c p$ for algal viruses [26-28]. However, and to the best of our knowledge, no inclusive attempt has been made until now to incorporate the signature genes of various viral groups in the same study. Moreover freshwater European ecosystems have not been investigated yet with such a battery of viral genetic markers.

Lake Geneva (Léman) is the largest lake in Western Europe lying between Switzerland and France. Although this ecosystem has been monitored by the International Commission for the Protection of Lake Geneva Waters (CIPEL in French abbreviation) since the early 1950s, information on the microbial community (including viruses) dynamics and diversity available in the literature is still scarce [29-31]. Duhamel et al. (2006) [29] highlighted for the first time that the viral community of this lake could be important and might play a key role in microbial processes. The study of Personnic et al. (2009a) [30] confirmed a few years later host-parasite links between viruses and chlorophyll $a$, or between viruses and bacteria. Their study also revealed that Synechococcus spp. is the most dominant picophytoplanktonic group in Lake Geneva and the abundances of picoplankton and viruses fluctuate seasonally. At last, using a modified dilution method, these authors found a significant impact of viruses on the prokaryotic community during the most productive seasons [31]. However, the diversity in terms of genome size or about some particular groups has never been studied for the viroplankton of Lake Geneva. We thus determined for the first time the diversity of various viral groups using some signature genes using polymerase chain reaction denaturing gradient gel electrophoresis (PCR-DGGE), quantified them using flow cytometry (FCM) and quantitative PCR (qPCR) and obtained a whole community profiling of viral communities using pulse field gel electrophoresis (PFGE). Our aim was to propose a preliminary picture of viral gene richness in Lake Geneva and to highlight the importance and seasonal dynamics of different viral groups. In addition, we tried to relate such richness to potential autotrophic hosts and the influence of key environmental factors on the dynamics of specific viral communities in Lake Geneva.

\section{Materials and methods}

\subsection{Study site and sampling strategy}

Lake Geneva which lies at an altitude of $372 \mathrm{~m}$ forms the border between France and Switzerland at the north of the French Alps and it is a $72 \mathrm{~km}$ long ecosystem with an area of $582 \mathrm{~km}^{2}$ and maximum width of $13 \mathrm{~km}$. It is a meromictic lake, never covered by ice, with temperature ranging between 4 and $22^{\circ} \mathrm{C}$. It holds an approximate volume of $89 \times 10^{9} \mathrm{~m}^{3}$ and this lake has been reported as eutrophic during the seventies and has changed following restoration programs to a mesotrophic state during the nineties in response to appropriate measurements taken to reduce phosphorus inputs to the lake. In 2011, the lake had a total phosphorus content of $27 \mu \mathrm{gP} \mathrm{L}^{-1}$ (CIPEL 2012). 
Samples were collected at the reference station (named SHL2), corresponding to the deepest part of the lake at $46^{\circ} 27^{\prime}$ lat. $\mathrm{N} 6^{\circ} 32^{\prime}$ long, $309 \mathrm{~m}$ deep, once or twice every month from July to November, 2011. A $20 \mathrm{~L}$ water sample was collected in the 0-20 m layer using a hose and pump (developed at INRA, Thonon). Samples collected in a polycarbonate container were stored at ambient temperature, protected from light and heat, and brought to the lab, within $3 \mathrm{~h}$ of collection. Upon reaching the laboratory, samples were immediately pre-filtered through a $60 \mu \mathrm{m}$ mesh filter, and then through glass fibre filter (GFF) and $1 \mu \mathrm{m}$ filters to remove zooplankton and phytoplankton. The viruses were concentrated further using a 30KDa cut off spiral wound tangential flow filtration (TFF) cartridge (Prep scale, TFF $1 \mathrm{ft}^{2}$, Millipore Inc, USA). A $200 \mathrm{ml}$ viral concentrate was stored at $4{ }^{\circ} \mathrm{C}$ for further analysis (i.e. the PCR, PFGE etc. see below). An aliquot of this viral concentrate was filtered through a $0.22 \mu \mathrm{m}$ filter to remove bacterial contamination and this mixture was used for PCR analysis. Alternatively, $2 \mathrm{~L}$ of the sample was also filtered through a polycarbonate $0.22 \mu$ filter that was stored at $-20^{\circ} \mathrm{C}$ for the detection of the (pico)cyanobacteria. The genomic DNA was extracted using PureLink genomic DNA extraction kit (Invitrogen, USA) following the manufacturer's instructions.

\subsection{Environmental parameters and plankton analysis}

A multiparameter probe was used to collect different parameters such as light, conductivity, and temperature while samples for chemical analysis brought back to the laboratory were analysed using standardised methods (see [32] for more details). Measurements of nitrate $\left(\mathrm{N}-\mathrm{NO}_{3}\right)$, nitrite $\left(\mathrm{N}-\mathrm{NO}_{2}\right)$, total nitrogen (Ntot), phosphate $\left(\mathrm{PO}_{4}\right)$, total phosphorous (Ptot) and silicate $\left(\mathrm{SiO}_{2}\right)$ were obtained. Raw water samples for the phytoplankton analysis were taken with a patented integrating instrument developed by Pelletier and Orand (1978) [33] and fixed with a few drops of Lugol's solution. For each sample analyzed a few days after sampling, $25 \mathrm{ml}$ were poured into an Utermöhl room (cylinder surmounting a blade with sediment chamber; [34]) and left to form a deposit for at least 12 hours safe from light and heat. The qualitative and quantitative examination of the phytoplankton was carried out using inverted microscopy (Zeiss). For the zooplankton, vertical sampling from a depth of $50 \mathrm{~m}$ to the surface was carried out using a net of $212 \mu \mathrm{m}$ mesh size. The samples were fixed with formol at $5 \%$. The enumeration of microcrustaceae presented here was achieved by means of a standard microscope (Olympus BX40).

\subsection{Flow cytometry analysis}

Viruses were counted using a FACSCalibur flow cytometer (FCM) (Becton Dickinson) equipped with an air cooled laser providing $15 \mathrm{~mW}$ at $488 \mathrm{~nm}$. Samples were fixed with glutaraldehyde $(0.5 \%$ final concentration, grade I, Merck) for $30 \mathrm{~min}$, then diluted in $0.02 \mu \mathrm{m}$ filtered Tris ethylenediaminetetraacetic acid (EDTA) buffer (referred to as TE, $0.1 \mathrm{mM}$ Tris-HCL and $1 \mathrm{mM}$ EDTA, $\mathrm{pH}$ 8), and incubated with SYBR Green I (at a final $10^{-4}$ dilution of the commercial stock solution; Molecular Probes), for $5 \mathrm{~min}$ at ambient temperature in the dark, followed by an incubation for $10 \mathrm{~min}$ at $75^{\circ} \mathrm{C}$, and then for another $5 \mathrm{~min}$ at room temperature, prior to FCM analysis [30]. The analysis of heterotrophic bacteria was done as for the viruses but without heating at $75^{\circ} \mathrm{C}$ and by using $<0.02 \mu \mathrm{m}$ filter lake instead of TE. The picocyanobacteria and other smaller 
phytoplankters were analysed without fixing or staining by using their natural autofluorescence. Analysis was made on samples to which a suspension of $1-\mu \mathrm{m}$ beads had been added (Molecular probes). Flow cytometer listmode files obtained were then transferred and analyzed on a PC using the custom-designed freeware CYTOWIN [35].

\subsection{Polymerase chain reaction (PCR)}

PCR was conducted separately for the different viral groups, after optimization of the PCR conditions, as shown in Table 1. CPS1/2, CPS4GC/5 and CPS 1.1/8.1 were used for the detection of cyanomyoviruses using the $g 20$ gene. MZPA1B F/R was used for the detection of the $g 23$ gene of cyanomyoviruses. pol $\mathrm{F} / \mathrm{R}$ was used for the detection of the DNA polymerase gene of the cyanopodoviruses. Another primer, Jason F/R, that was designed in a previous study [36], aimed at detecting the DNA polymerase gene of cyanopodovirus from lacustrine environments as we found difficulty in testing our samples with the pol F/R primer [11]. Double-stranded DNA algal virus (e.g. PhycoDNAviridae) detection was performed using $m c p \mathrm{~F} / \mathrm{R}$ and AVS1/2 polB primers. The presence of host photosynthetic genes in viral genomes was detected using $p s b A$ and $p s b D$ primers. The picocyanobacterial detection was done using CYA F/R. 1 to $2 \mu$ of the $<0.22 \mu \mathrm{m}$ concentrate was used for the PCR and the reactions were performed in $30 \mu$ final volume. $10 \mu \mathrm{l}$ of the sample was used for gel electrophoresis in $1.5 \%$ agarose gel. The products were visualised in a gel documentation system and images were captured (Biorad, Germany).

\subsection{DGGE-PCR}

DGGE analysis was performed using the CBS-DGGE 2000 system (C.B.S. Scientific Co., Inc.). PCR products $(20 \mu \mathrm{l})$ were loaded onto a 0.75 -mm-thick $6 \%$ polyacrylamide gel in $1 \times$ TAE buffer with 45 to $70 \%$ linear denaturing gradient. Electrophoresis was performed at a constant voltage of $120 \mathrm{~V}$ and a temperature of $60^{\circ} \mathrm{C}$ for the optimal duration of $16 \mathrm{~h}$. Gels were stained for $45 \mathrm{~min}$ in the dark with SybrGold (Molecular Probes). The gels were visualized and photographed using a gel documentation system (Biorad, Germany).

\section{6. $P F G E$}

Pulse Field Gel Electrophoresis analysis was performed using a BioRad DR II CHEF electrophoresis system (Biorad, Germany). A $35 \mathrm{ml}$ sample of viral concentrate after ultrafiltration was precipitated with polyethylene glycol $8,000(10 \% \mathrm{w} / \mathrm{v}$ in final concentration) and $\mathrm{NaCl}(0.6 \% \mathrm{w} / \mathrm{v}$ in final concentration $)$ for $24 \mathrm{~h}$ at $4{ }^{\circ} \mathrm{C}$ [37]. The precipitated viral particles were concentrated by centrifugation at $15,000 \mathrm{~g}$ for $1 \mathrm{~h}$ (Beckman JA-30.50). The supernatant was discarded and the viral pellets were suspended in 100-200 $\mu \mathrm{l}$ sterile MilliQ water and stored at $4^{\circ} \mathrm{C}$ for further analysis. Equal volumes of the viral concentrate and molten $\left(50^{\circ} \mathrm{C}\right) 1.5 \%$ InCert agarose $(\mathrm{REF})$ were mixed, vortexed and dispensed into plug moulds. After solidification of the gel, plugs were treated with lysis buffer $\left(1 \% \mathrm{SDS}, 0.5 \mathrm{M}\right.$ EDTA and $20 \mathrm{mg} / \mu \mathrm{l}$ proteinase $\mathrm{K}$ ) for $24 \mathrm{~h}$ at $37^{\circ} \mathrm{C}$. Plugs were then washed 3 times with wash buffer (0.5 M EDTA, $\mathrm{pH} 8.0$ ), loaded into $1 \%$ agarose gel and separated both large and small viral genomes using ramp conditions (i) 10 to $40 \mathrm{~s}$ switch time for $18 \mathrm{~h}$ (ii) 1 to $5 \mathrm{~s}$ switch time for $12 \mathrm{~h}$. Gels were stained with ethidium 
Table 1. List and characteristics of the primers used in this study.

\begin{tabular}{|c|c|c|c|c|}
\hline Primer set & $\begin{array}{l}\text { Targeted gene and } \\
\text { group }\end{array}$ & $\begin{array}{c}\text { Primer sequence PCR } \\
\text { conditions }\end{array}$ & $\begin{array}{l}\text { Product } \\
\text { size }\end{array}$ & Reference \\
\hline CPS $1 / 2$ & $\begin{array}{l}\text { g20, capsid protein, } \\
\text { Cyanophages }\end{array}$ & $\begin{array}{l}\text { CPS1: } \\
\text { GTAGWATTTTCTACA- } \\
\text { TTGAYGTTGG } \\
\text { CPS2: } \\
\text { GGTARCCAGAAATC- } \\
\text { YTCMAGCAT } \\
40 \text { cycles at } 94^{\circ} \mathrm{C} 45 \mathrm{~S} \\
48^{\circ} \mathrm{C} 45 \mathrm{~S} \text {, and } 72^{\circ} \mathrm{C} \text { for } 45 \mathrm{~S} \\
\text { With } 5 \text { min of initial dena- } \\
\text { turation and final } \\
\text { extension }\end{array}$ & $165 \mathrm{bp}$ & $\begin{array}{l}\text { [53] Fuller et al. } \\
1998\end{array}$ \\
\hline CPS4GC/5 & $\begin{array}{l}\text { g20, capsid protein } \\
\text { cyanophages }\end{array}$ & $\begin{array}{l}\text { CPS4: } \\
\text { GTAGAATTTTCTACA- } \\
\text { YYGATGTTGG } \\
\text { CPS5:GGTAACCAGAAA- } \\
\text { TCTTCAAGCAT } \\
40 \text { cycles at } 94^{\circ} \mathrm{C} 45 \mathrm{~S} \\
48^{\circ} \mathrm{C} 45 \mathrm{~S} \text {, and } 72^{\circ} \mathrm{C} \text { for } 45 \mathrm{~S} \\
\text { With } 5 \text { min of initial dena- } \\
\text { turation and final } \\
\text { extension }\end{array}$ & $165 \mathrm{bp}$ & $\begin{array}{l}\text { Wilson et al. } \\
1999\end{array}$ \\
\hline CPS1.1/8.1 & $\begin{array}{l}\text { g20, capsid protein, } \\
\text { cyanophages }\end{array}$ & $\begin{array}{l}\text { CPS1.1:GTAGWATWTTY- } \\
\text { TAYATTGAYGTWGG } \\
\text { CPS8.1:ARTAYTTDCCDA- } \\
\text { YRWAWGGWTC } \\
40 \text { cycles at } 94^{\circ} \mathrm{C} 45 \mathrm{~S} \\
46^{\circ} \mathrm{C} 45 \mathrm{~S} \text {, and } 72^{\circ} \mathrm{C} \text { for } 45 \mathrm{~S} \\
\text { With } 5 \text { min of initial dena- } \\
\text { turation and final } \\
\text { extension }\end{array}$ & $592 \mathrm{bp}$ & $\begin{array}{l}\text { [16] Sullivan } \\
\text { et al. } 2008\end{array}$ \\
\hline MZPA1B F/R & $\begin{array}{l}\text { g23, capsid protein, } \\
\text { cyanomyovirus }\end{array}$ & $\begin{array}{l}\text { MZPA1B: GATATTTGI } \\
\text { GGIGTTCAGCCIATGA } \\
\text { MZIA6: CGCGGTTGA } \\
\text { TTTCCAGCATGATTTC } \\
40 \text { cycles at } 94^{\circ} \mathrm{C} 30 \mathrm{~S} \\
48^{\circ} \mathrm{C} 30 \mathrm{~S} \text {, and } 72^{\circ} \mathrm{C} \text { for } 30 \mathrm{~S} \text {, } \\
\text { with } 5 \text { min of initial dena- } \\
\text { turation and final } \\
\text { extension }\end{array}$ & $550 \mathrm{bp}$ & Filee et al. 2005 \\
\hline ProPsbA F/R & $\begin{array}{l}\text { D1, photosyne- } \\
\text { thetic genes in } \\
\text { cyanophages }\end{array}$ & $\begin{array}{l}\text { ProPsb AF: AACATCA } \\
\text { TYTCWGGTGCWGT } \\
\text { ProPsb AR: TCGTGCA } \\
\text { TTACTTCCATACC } \\
40 \text { cycles at } 94^{\circ} \mathrm{C} 30 \mathrm{~S} \\
45^{\circ} \mathrm{C} 30 \mathrm{~S} \text {, and } 72^{\circ} \mathrm{C} \text { for } 30 \mathrm{~S}, \\
\quad \text { with } 5 \text { min of initial dena- } \\
\text { turation and final } \\
\text { extension }\end{array}$ & $650-800 \mathrm{bp}$ & $\begin{array}{l}\text { [51] Sullivan } \\
\text { et al. } 2006\end{array}$ \\
\hline
\end{tabular}


Table 1. Continued.

\begin{tabular}{|c|c|c|c|c|}
\hline Primer set & $\begin{array}{l}\text { Targeted gene and } \\
\text { group }\end{array}$ & $\begin{array}{c}\text { Primer sequence PCR } \\
\text { conditions }\end{array}$ & $\begin{array}{l}\text { Product } \\
\text { size }\end{array}$ & Reference \\
\hline$p s b D \mathrm{~F} / \mathrm{R}$ & $\begin{array}{l}\text { D2, photosynthetic } \\
\text { genes in } \\
\text { cyanophages }\end{array}$ & $\begin{array}{l}40 \text { cycles at } 94^{\circ} \mathrm{C} 30 \mathrm{~S} \\
45^{\circ} \mathrm{C} 30 \mathrm{~S} \text {, and } 72^{\circ} \mathrm{C} \text { for } 30 \mathrm{~S} \\
\text { With } 5 \mathrm{~min} \text { of initial dena- } \\
\text { turation and final } \\
\text { extension }\end{array}$ & $383 \mathrm{bp}$ & $\begin{array}{l}\text { [23] Clokie et al. } \\
2006\end{array}$ \\
\hline Jason $\mathrm{F} / \mathrm{R}$ & $\begin{array}{l}\text { DNA polymerase } \\
\text { gene, } \\
\text { Cyanopodovirus }\end{array}$ & $\begin{array}{l}\text { Jason F: ACTGCA } \\
\text { ACGCCTGGGATGGTG } \\
\text { Jason R: AGCAAT } \\
\text { GCGGCGACCGTCAA } \\
40 \text { cycles at } 94^{\circ} \mathrm{C} 30 \mathrm{~S} \\
50^{\circ} \mathrm{C} 30 \mathrm{~S} \text {, and } 72^{\circ} \mathrm{C} \text { for } 30 \mathrm{~S} \\
\text { With } 5 \text { min of initial dena- } \\
\text { turation and final } \\
\text { extension }\end{array}$ & $380-480$ bp & $\begin{array}{l}\text { Present study } \\
\text { [36] Jacquet } \\
\text { et al. } 2012\end{array}$ \\
\hline$M c p \mathrm{~F} / \mathrm{R}$ & $\begin{array}{l}\text { Major capsid pro- } \\
\text { tein, } \\
\text { phycodnaviridae }\end{array}$ & $\begin{array}{l}\text { MCP F: GGYGGYCAR } \\
\text { CGYATT } \\
\text { MCP R: TGIARYTGY } \\
\text { TCRAYIAGGTA } \\
40 \text { cycles at } 94^{\circ} \mathrm{C} 30 \mathrm{~S} \\
48^{\circ} \mathrm{C} 30 \mathrm{~S} \text {, and } 72^{\circ} \mathrm{C} \text { for } 30 \mathrm{~S}, \\
\quad \text { with } 5 \text { min of initial dena- } \\
\text { turation and final } \\
\text { extension }\end{array}$ & $347-518 \mathrm{bp}$ & $\begin{array}{l}\text { [28] Larsen et al. } \\
2008\end{array}$ \\
\hline AVS $1 / 2$ & $\begin{array}{l}\text { DNA polymerase } \\
\text { gene, } \\
\text { Phycodnaviridae }\end{array}$ & $\begin{array}{l}\text { AVS F: GARGGIGCIA } \\
\text { CIGTIYTIGAYGC } \\
\text { AVS R: GCIGCRTAI } \\
\text { CKYTTYTTISWRTA } \\
40 \text { cycles at } 94^{\circ} \mathrm{C} 30 \mathrm{~S} \\
48^{\circ} \mathrm{C} 30 \mathrm{~S} \text {, and } 72^{\circ} \mathrm{C} \text { for } 30 \mathrm{~S}, \\
\text { with } 5 \text { min of initial dena- } \\
\text { turation and final } \\
\text { extension }\end{array}$ & $700 \mathrm{bp}$ & $\begin{array}{l}\text { Culley et al., } \\
2008\end{array}$ \\
\hline Pol F/R & $\begin{array}{l}\text { DNA polymerase } \\
\text { gene, } \\
\text { Cyanopodovirus }\end{array}$ & $\begin{array}{l}\text { CP-DNAP-349 F: CCAAA } \\
\text { YCTYGCMCARGT } \\
\text { CP-DNAP-533Ra: CTCG } \\
\text { TCRTGSACRAASGC } \\
\text { CP-DNAP-533RB:CTCG } \\
\text { TCRTGDATRAASGC } \\
40 \text { cycles at } 94^{\circ} \mathrm{C} 30 \mathrm{~S} \\
50^{\circ} \mathrm{C} 30 \mathrm{~S} \text {, and } 72^{\circ} \mathrm{C} \text { for } 30 \mathrm{~S} \text {, } \\
\text { with } 5 \text { min of initial dena- } \\
\text { turation and final } \\
\text { extension }\end{array}$ & $650-750 \mathrm{bp}$ & $\begin{array}{l}\text { [11] Chen et al., } \\
\text { 2009, } \\
\text { Huang et al., } \\
2010\end{array}$ \\
\hline
\end{tabular}


bromide for $24 \mathrm{~h}$, visualized and photographed using a gel documentation system (Biorad, Germany).

\subsection{Quantitative PCR ( $q P C R$ )}

qPCR analysis was performed in the Rotor gene system (Stratagene) to give estimates of cyanopodovirus and cyanomyovirus abundances. The primers were added at a concentration of $5 \mathrm{pm}$ to Qiagen SYBR Green mix and the reaction was performed in $20 \mu 1$ volume in triplicate. A $2 \mu \mathrm{l}$ of the $<0.2 \mu \mathrm{m}$ viral concentrate was used for PCR. qPCR conditions were the same as for normal PCR for the respective genes. A standard curve was created for each of these genes using $10^{7}$ to $10^{-1}$ copies of respective cloned genes from known viral cultures. qPCR efficiency was tested (not shown). We assumed that there was only 1 gene copy per cyanoviral particle [38]. After the run, the samples were quantified by importing the standard curves and the viruses are reported as number of gene copies/ml of the water sample (taking into account and using appropriate conversion and dilution factors).

\subsection{Gel comparison}

The PFGE and DGGE banding patterns were analyzed by considering both the presence and relative abundance of bands using the GelCompare II software package (Applied Maths, Kortrijk, Belgium) and the Paleontological Statistics Software Package for education and Software analysis (PAST version 2.14) [39]. Briefly, fingerprinting patterns were first standardized with a reference pattern. Each band was described by its position and its relative intensity in the profiles, which could be described as the ratio between the surface of the peak and the sum of the surfaces for all the peaks within the profile. A similarity matrix between densitometric curves of the band patterns was calculated based on the Bray-Curtis index and used to perform unweighted pair group cluster (UPGMA).

\subsection{Statistical analysis}

Statistical analysis was only performed using Spearman's correlation (with ExcelStat) to highlight the relationships between the different variables and with viral diversity through the number of DGGE bands.

\section{Results}

\subsection{Environmental parameters}

The values for the main environmental parameters are provided in Table 2. Temperature was relatively warm and evolved on average between $14.2 \pm 4.6^{\circ} \mathrm{C}$ (July) and $18.9 \pm 4.3^{\circ} \mathrm{C}$ (November) when integrated over the 0-20 m layer. Near the surface, it could reach up to $21.5^{\circ} \mathrm{C}$ in August and dropped to around $7.7^{\circ} \mathrm{C}$ near $20 \mathrm{~m}$ in November. The highest oxygen concentration was recorded in early July with approximately $10 \pm 1.01 \mu \mathrm{g} \mathrm{O}_{2} \mathrm{~L}^{-1}$ and values remained relatively high, i.e. between 9 and $10 \mu \mathrm{g} \mathrm{O}_{2} \mathrm{~L}^{-1}$, between July and October, while a significant decrease occurred in November with $7.5 \pm 1.5 \mu \mathrm{g} \mathrm{O}_{2} \mathrm{~L}^{-1}$. Total phosphorus and orthophosphates varied between $6.6 \pm 0.8$ (November) and $13.8 \pm 3.9$ (July) $\mu \mathrm{gP} \mathrm{L}^{-1}$ and between $3 \pm 0.5$ (October) and $6.6 \pm 0.5$ (August) $\mu \mathrm{gPL}^{-1}$, respectively. Comparatively 
Table 2. Evolution of the main environmental parameters in Lake Geneva in the 0-20 m layer.

\begin{tabular}{|c|c|c|c|c|c|}
\hline Parameters & July & August & September & October & November \\
\hline Temperature ${ }^{\circ} \mathrm{C}$ & $\begin{array}{l}14.19 \\
\pm 4.6\end{array}$ & $\begin{array}{l}16.67 \\
\pm 6.2\end{array}$ & $\begin{array}{l}18.19 \\
\pm 6.9\end{array}$ & $\begin{array}{l}17.22 \\
\pm 5.87\end{array}$ & $\begin{array}{l}17.65 \\
\pm 4.3\end{array}$ \\
\hline Oxygen $\mathrm{mg} / \mathrm{L}$ & $\begin{array}{c}9.96 \\
\pm 1.01\end{array}$ & $\begin{array}{c}9.25 \\
\pm 0.37\end{array}$ & $\begin{array}{c}9.56 \\
\pm 0.35\end{array}$ & $\begin{array}{c}8.90 \\
\pm 1.04\end{array}$ & $\begin{array}{l}7.46 \\
\pm 1.5\end{array}$ \\
\hline Chlorophyll a $\mu \mathrm{g} / \mathrm{L}$ & $\begin{array}{l}4.89 \\
\pm 1.3\end{array}$ & $\begin{array}{c}4.55 \\
\pm 1.52\end{array}$ & $\begin{array}{c}2.99 \\
\pm 0.95\end{array}$ & $\begin{array}{c}2.89 \\
\pm 0.58\end{array}$ & $\begin{array}{c}4.46 \\
\pm 1.53\end{array}$ \\
\hline pH no unit & $\begin{array}{c}8.35 \\
\pm 0.33\end{array}$ & $\begin{array}{c}8.47 \\
\pm 0.41\end{array}$ & $\begin{array}{c}8.37 \\
\pm 0.27\end{array}$ & $\begin{array}{c}8.24 \\
\pm 0.26\end{array}$ & $\begin{array}{c}7.81 \\
\pm 0.13\end{array}$ \\
\hline Light $\mu \mathrm{E}$ & $\begin{array}{c}187.57 \\
\pm 189.44\end{array}$ & $\begin{array}{l}144.39 \\
\pm 61.95\end{array}$ & $\begin{array}{l}73.00 \\
\pm 4.6\end{array}$ & $\begin{array}{c}196.23 \\
\pm 301.52\end{array}$ & $\begin{array}{l}100.21 \\
\pm 152.4\end{array}$ \\
\hline Transp m & $\begin{array}{c}5.6 \\
\pm 1.6\end{array}$ & $\begin{array}{l}10.5 \\
\pm 2.1\end{array}$ & $\begin{array}{l}11.2 \\
\pm 1.8\end{array}$ & $\begin{array}{l}10.6 \\
\pm 2.7\end{array}$ & $\begin{array}{l}11.6 \\
\pm 1.7\end{array}$ \\
\hline Ptot $\mathrm{mg} / \mathrm{L}$ & $\begin{array}{c}0.0138 \\
\pm 0.0039\end{array}$ & $\begin{array}{l}0.0106 \\
\pm 0.011\end{array}$ & $\begin{array}{c}0.0166 \\
\pm 0.0011\end{array}$ & $\begin{array}{c}0.0106 \\
\pm 0.0017\end{array}$ & $\begin{array}{c}0.0066 \\
\pm 0.0008\end{array}$ \\
\hline $\mathrm{P}-\mathrm{PO}_{4} \mathrm{mg} / \mathrm{L}$ & $\begin{array}{c}0.0038 \\
\pm 0.0019\end{array}$ & $\begin{array}{c}0.0066 \\
\pm 0.0005\end{array}$ & $\begin{array}{c}0.0032 \\
\pm 0.0050\end{array}$ & $\begin{array}{c}0.003 \\
\pm 0.0005\end{array}$ & $\begin{array}{c}0.0036 \\
\pm 0.0005\end{array}$ \\
\hline Ntot $\mathrm{mg} / \mathrm{L}$ & $\begin{array}{c}0.579 \\
\pm 0.858\end{array}$ & $\begin{array}{c}0.436 \\
\pm 0.172\end{array}$ & $\begin{array}{c}0.474 \\
\pm 0.0718\end{array}$ & $\begin{array}{c}0.28 \\
\pm 0.288\end{array}$ & $\begin{array}{l}0.666 \\
\pm 0.07\end{array}$ \\
\hline $\mathrm{N}-\mathrm{NO}_{3} \mathrm{mg} / \mathrm{L}$ & $\begin{array}{c}0.354 \\
\pm 0.087\end{array}$ & $\begin{array}{c}0.2 \\
\pm 0.24\end{array}$ & $\begin{array}{c}0.156 \\
\pm 0.195\end{array}$ & $\begin{array}{l}0.096 \\
\pm 0.22\end{array}$ & $\begin{array}{c}0.522 \\
\pm 0.078\end{array}$ \\
\hline $\mathrm{N}-\mathrm{NH}_{4} \mathrm{mg} / \mathrm{L}$ & $\begin{array}{c}0.008 \\
\pm 0.0067\end{array}$ & $\begin{array}{c}0.011 \\
\pm 0.002\end{array}$ & $\begin{array}{l}0.0068 \\
\pm 0.002\end{array}$ & $\begin{array}{l}0.0132 \\
\pm 0.006\end{array}$ & $\begin{array}{l}0.0102 \\
\pm 0.002\end{array}$ \\
\hline $\mathrm{SiO}_{2} \mathrm{mg} / \mathrm{L}$ & $\begin{array}{l}0.262 \\
\pm 0.33\end{array}$ & $\begin{array}{l}0.256 \\
\pm 0.51\end{array}$ & $\begin{array}{l}0.204 \\
\pm 0.58\end{array}$ & $\begin{array}{l}0.368 \\
\pm 0.38\end{array}$ & $\begin{array}{l}1.108 \\
\pm 0.25\end{array}$ \\
\hline $\mathrm{COT} \mathrm{mg/L}$ & $\begin{array}{c}1.296 \\
\pm 0.289\end{array}$ & $\begin{array}{c}1.086 \\
\pm 0.618\end{array}$ & $\begin{array}{l}1.198 \\
\pm 0.27\end{array}$ & $\begin{array}{l}1.308 \\
\pm 0.24\end{array}$ & $\begin{array}{c}0.834 \\
\pm 0.064\end{array}$ \\
\hline
\end{tabular}

$\mathrm{N}-\mathrm{NO}_{3}$ was relatively high varying between $96 \pm 22$ (October) and $522 \pm 78$ (November) $\mu \mathrm{gNL}^{-1}$ while $\mathrm{N}^{-\mathrm{NH}_{4}}$ ranged between $8 \pm 6.7$ (July) and $13 \pm 6$ (October) $\mu \mathrm{gP} \mathrm{L}^{-1}$. The ratio between total $\mathrm{N}$ and $\mathrm{P}$ (from 23 to 100 ) supported the idea that $\mathrm{P}$ was probably limiting but it has also been reported recently that $\mathrm{N}$ can be limiting for phytoplankton growth in Lake Geneva [40]. Finally, $\mathrm{SiO}_{2}$ was the lowest in September with $204 \pm 58 \mu \mathrm{g} \mathrm{L}^{-1}$, while the highest value recorded was $1.1 \pm 2.5 \mathrm{mg} \mathrm{L}^{-1}$ in November. This period was very sunny and the transparency varied between $5.6 \pm 1.6$ (July) and 11.2 \pm 1.8 (November) m. Chlorophyll $a$ concentrations ranged from $2.9 \pm 0.58$ in October to $4.9 \pm 1.3 \mu \mathrm{g} \mathrm{L}^{-1}$ in July. Heavy winds were recorded in October-November (data not shown).

\subsection{Abundances of the microbial, phytoplankton and zooplankton communities}

The abundance of the heterotrophic bacteria was on average about $2.5 \times 10^{6} \mathrm{cells} \mathrm{ml}^{-1}$ but concentrations varied between $9.35 \times 10^{5} \pm 2.93 \times 10^{5}$ cells ml $^{-1}$ (November) and $4.3 \times$ 

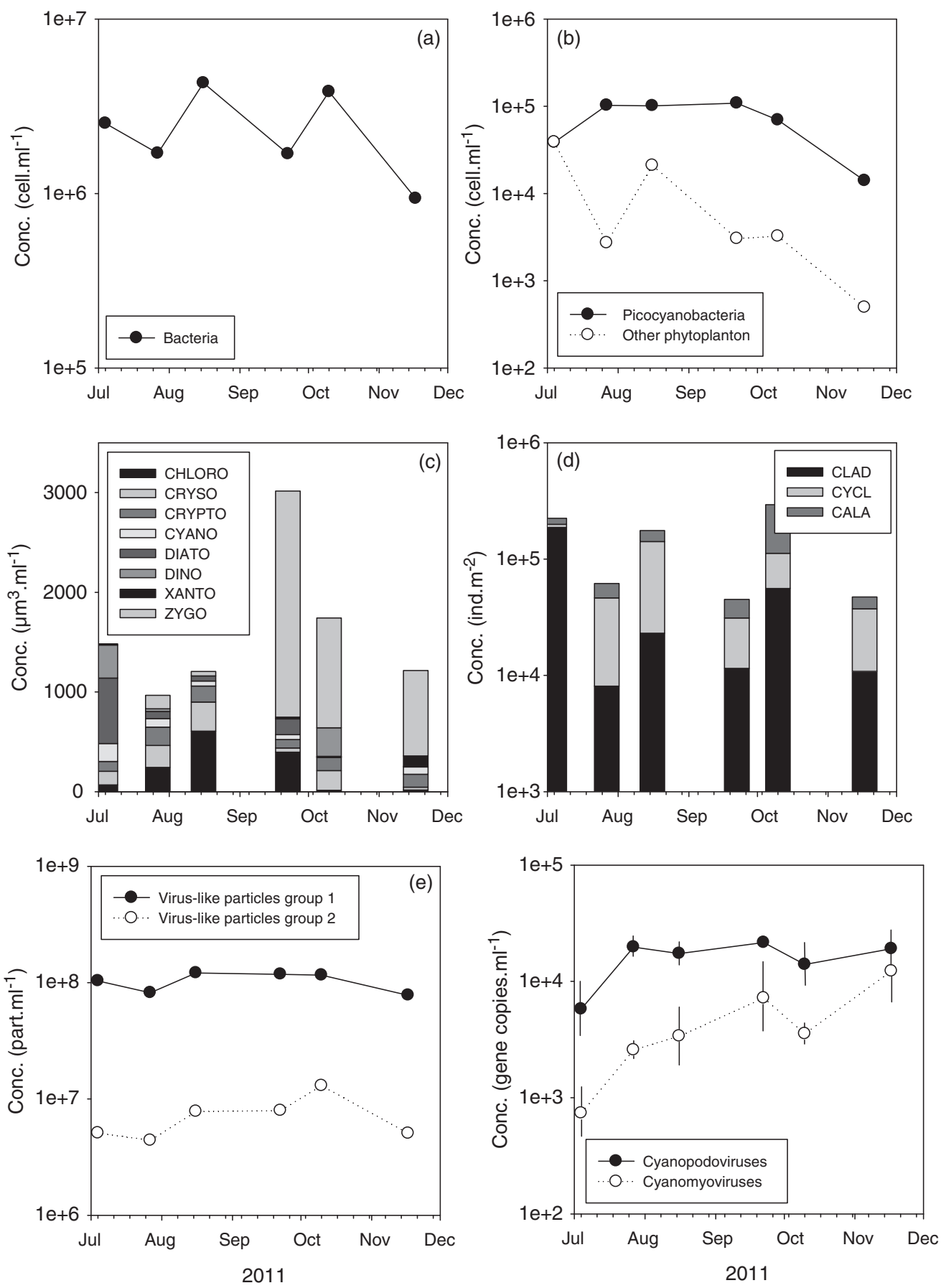

Figure 1. Abundances of the heterotrophic bacteria (A) and the picocyanobacteria and all other phytoplankters (B) obtained using flow cytometry. Biomass of phytoplanktonic (C) and zooplanktonic groups (D) counted by microscopy. Abundances of virus-like particles groups 1 and 2 (E) and of the cyanomyo- and cyanopodo-viruses $(\mathrm{F})$. 
$10^{6} \pm 2.91 \times 10^{6}$ cells ml $^{-1}$ (August) when integrated over the $0-20 \mathrm{~m}$ layer (Figure 1a). There were significant variations in the picocyanobacterial and other phytoplanktonic abundances (Figure 1b), as observed using FCM, during the period of study. The lowest picocyanobacterial abundance was recorded in November with $1.4 \times 10^{4} \pm$ $2.09 \times 10^{4}$ cells ml $^{-1}$ and the highest concentrations were recorded between the end of July and the end of September with approximately $1.1 \times 10^{5} \pm 6.65 \times 10^{4} \mathrm{cells} \mathrm{ml}^{-1}$. For the other (grouped) phytoplankters we could detect using FCM, there was a clear decrease from early summer $\left(3.9 \times 10^{4}\right.$ cells ml $\left.{ }^{-1}\right)$ to the end of fall $\left(4.9 \times 10^{2}\right.$ cells ml $\left.^{-1}\right)$ but the proportion of the different populations changed throughout the period of study as already mentioned elsewhere [41]. The phytoplankton analysis was made complete using microscopy. Between July and November the biomass and the dominance of the phytoplankton species counted by microscopy changed dramatically (Figure 1c). The biomass varied between 380 (November) and 3000 (September) $\mu \mathrm{g} \mathrm{L}^{-1}$. Diatoms (mainly Fragilaria crotonensis) dominated the phytoplankton biomass in early July, while it was a mixture of diatoms, chlorophyceae, crysophyceae, cryptophyceae, zygophyceae (i.e. Mougeotia gracillima) and cyanobacteria at the end of the same month. In August, chlorophyceae (Stichococcus bacillaris) was the dominant group followed in almost equivalent proportion by crysophyceae (Dinobryon spp.) and cryptophyceae (Rhodomonas, Cryptomonas). In September, the chlorophyceae remained an important group but zygophyceae (M. gracillima) were clearly the most populated. The same trend was recorded in October and November with an increasing proportion of the cryptophyceae. The microscopic analysis of the micro-crustacean community revealed significant changes over the different groups throughout the period of study, for both the cladocerans, cyclopoids, and calanoids (Figure 1d) and the proportion between the herbivorous and carnivorous forms also changed greatly (not shown). Briefly, cladocerans (i.e. Daphnia) were the dominant group in July, representing $85 \%$ of the total planktonic microcrustaceae. The following months, this community represented between 13\% (August) and $25 \%$ (September) of the microcrustacean community. The cyclopoids (e.g. Cyclops prealpinus) became the dominant community during summer months, i.e. between the end of July and the end of September, representing between 43 and $67 \%$ of the total zooplanktonic community. The calanoids (represented only by Eudiaptomus gracilis) were the dominant group only in October (62\%).

\subsection{Abundances of the viruses}

In Lake Geneva, high concentrations of virus-like particles (VLPs) have already been reported [29-31] and this study confirms also that these VLPs could be easily discriminated into two groups referred to as VLP1 and VLP2. It was previously reported that these two groups could be mainly associated with bacteriophages and cyanophages, respectively [30]. Over the 0-20 m layer, the concentration of the VLP1 varied in a relatively short range, between $7.8 \times 10^{7} \pm 1.84 \times 10^{7}$ (November) and $1.2 \times 10^{8} \pm 3.36 \times 10^{7}$ (August) part $\mathrm{mL}^{-1}$ while the abundance of VLP2 ranged from $4.42 \times 10^{6} \pm 2.59 \times 10^{6}$ (August) to $1.3 \times 10^{7} \pm 2.71 \times 10^{7}$ (October) part $\mathrm{mL}^{-1}$ (Figure 1e). Viral to bacterial ratio (VBR), i.e. the ratio of the viral abundance to the bacterial abundance which can be considered as a proxy of the relationships between these two communities, was in the range of 15 to 36 during the summer months. This ratio slowly increased to about 170 during the month of July (not shown). Among the viruses, we could quantify two groups of viruses belonging to 
the cyanophages, i.e. the cyanomyoviruses and the cyanopodoviruses throughout the copy numbers of the $g 20$ and polA genes counted by qPCR (Figure 1f). Cyanopodovirus concentration ranged between $5.8 \times 10^{3}$ (July) and $2.2 \times 10^{4}$ (September). The cyanomyoviral concentration as revealed by the CPS4/5 primer set ranged from $7.4 \times 10^{2}$ (July) to $1.2 \times 10^{4}$ (November). The same trend was recorded for CPS1/2 and we only showed the former (the correlation between the CPS1/2 and CPS4/5 abundances was $r=0.95$, not shown). The abundances of all the viral groups were thus relatively high from the end of July to September, representing the summer months. It was also evident from the qPCR analysis that changes in viral abundances were in concurrence with the abundance of the picocyanobacteria (see Discussion).

\subsection{Diversity of the different viral and prokaryotic groups}

The structure of the different targeted genes or groups revealed clear changes throughout the period of study, highlighting for most of the populations marked transitions, especially between summer and fall.

Firstly, the analysis using PFGE revealed the existence of 28 different viral bands corresponding to genome sizes ranging from 30 to $300 \mathrm{~kb}$ (Figure 2). The most abundant populations detected in each sample ranged from 10-17 with the lowest number of populations in July and the maximum at the summer-fall period. The most abundant groups were in the sizes $150-200 \mathrm{~kb}$ and $30-100 \mathrm{~kb}$ with bands of $35,38,48,75,95,160$, $170,190,200,230$ and $300 \mathrm{~kb}$ in common. The cluster analysis of PFGE patterns revealed two groups with a clear separation between early summer and the rest of the samples, i.e. early July vs. the other months. There was $>70 \%$ and $75 \%$ similarity between samples taken at the end of July and mid-August and for October and November months, respectively. September seemed to differ from the two previous clusters.

The PCR-DGGE analysis for the picocyanobacteria gave 9-18 bands, with nine bands detected in early summer (Figure 3). The maximum number of bands was recorded in September and then the amount decreased during fall. Only four bands were common to all samples. The cluster analysis revealed that the samples belonged to three clusters: July, August-September and October-November (Figure 4a) with a clear transition between summer and fall.

For the $g 20$ gene (Figures 3 and 4b), the number of bands ranged from 7 (July) to 14 (August and September). There were four common bands in all the samples. There were seven common bands in September to November and five in July and August. The cluster analysis revealed the existence of two main clusters with fall (October and November) samples clustering separately against the summer months. The similarity between the fall and the summer samples were however larger ( $>40 \%$ ) compared to the previous $16 \mathrm{~S}$ gene $(<10 \%)$. Interestingly, it seems that there was no difference in the structure of the cyanomyophages between the end of July and mid-August.

For the $g 23$ gene (Figures 3 and 4c), the number of bands ranged from 16 to 24. Sixteen bands were observed during fall and 24 in early summer. Twelve bands were common from July to October. The intensities of the bands were lower when compared to PCR-DGGE with other genes even though the PCR amplification was good. The highest diversity was observed in August and October. The cluster analysis indicated that October differed from the other months, a period for which we also previously found marked changes in viral and 

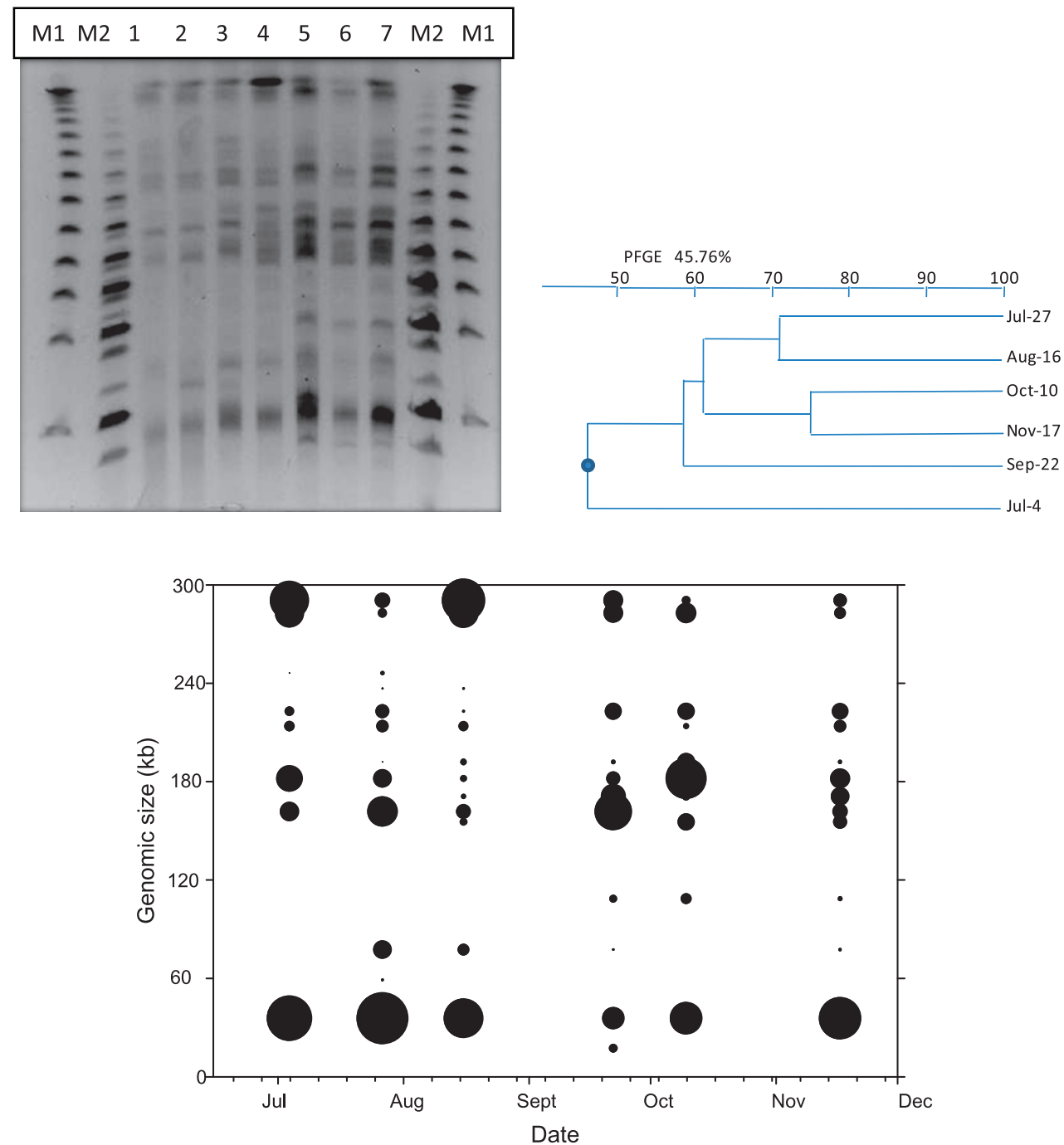

Figure 2. Gel and schematic outline of the relative abundance of viral populations determined by PFGE between July and November 2011, and output of the clustering analyses. M1 and M2 are Lambda and Midrange markers, 1-3 correspond to July samples, 4-August, 5-September, 6-October and 7-November.

bacterial abundances for peri-alpine lakes [30]. The similarity between all the samples (except for October) remained relatively large (between 65 and 80\%).

For the $p s b A$ gene (Figures 3 and 4d), the number of bands ranged from 6 to 13 with a minimum during spring and a maximum during summer. The $p s b A$ gene had the minimum number of bands during July and a maximum diversity during September. There was just one common band among the samples. The cluster analysis revealed two main clusters separating July-August to the rest of the period studied, the difference between these two groups of samples being relatively important (approximately 90\%). psbA diversity was $>50 \%$ similar during both summer and fall months. 


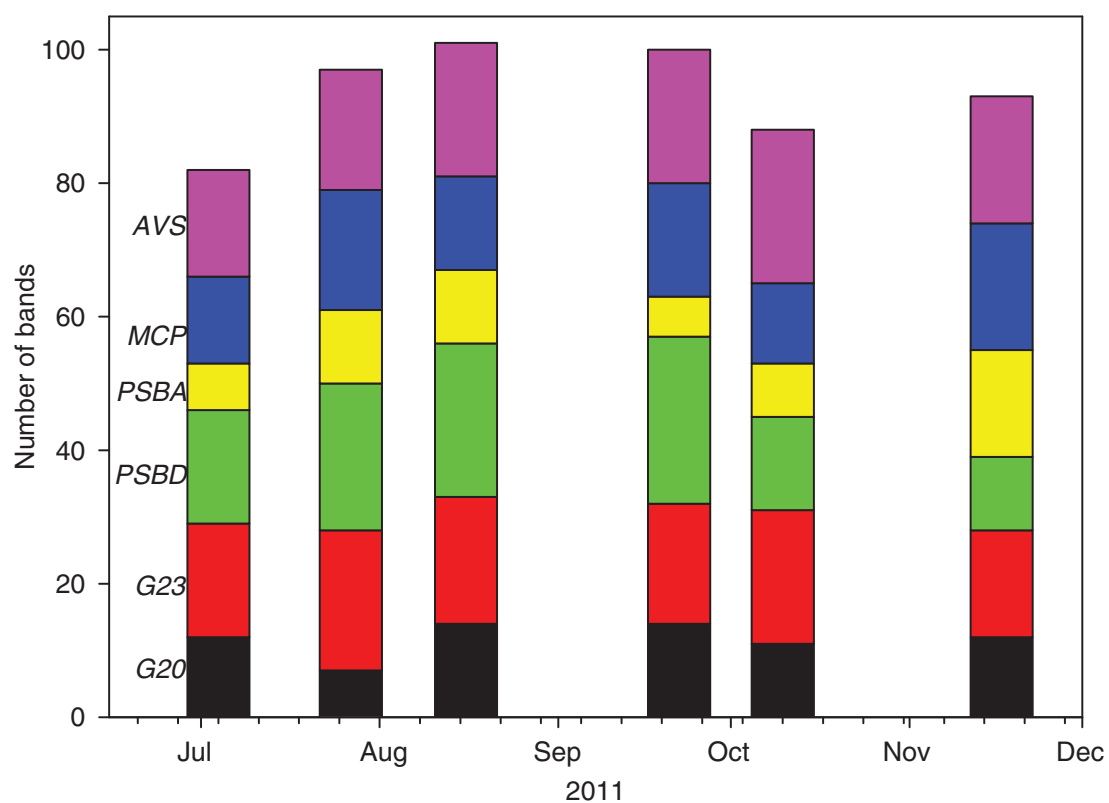

Figure 3. Evolution throughout the period of study of the DGGE bands numbers for viral signature genes.

$p s b D$ analysis showed the maximum diversity with the number of bands ranging from 11 (October and November) to 30 (in September, as for picocyanobacteria and $p s b A$ ). However, the number of common bands was only three. There were nine common bands from September to November. The cluster analysis separated the samples into three clusters: one in early July, a second in end July to mid-August, and a third for the fall months (Figures 3 and $4 \mathrm{e}$ ) with a high similarity ( $>90 \%$ ) between October and November. Differently said, it seems that this gene behaved differently than $p s b A$.

For the $m c p$ gene, the number of bands ranged from 12 to 19. There were nine common bands among the samples. The number of bands was more important during the summerfall transition period (September to November) and the peak of diversity was recorded in October. The cluster analysis showed a separation between October and the other months (Figures 3 and $4 \mathrm{f}$ ) as previously reported for $g 23$. However, the separation between the other months were different for these two genes. Typically, for $m c p$, September and November seemed more related to each other compared to the other months (July-August).

For the polB gene, the number of bands varied between 16 (early July) and 23 (October), and there were eight common bands among the samples. The diversity increased from summer till October and decreased in November. The cluster analysis revealed first a clear separation between August and the other months and then between July and the rest (i.e. September to November). The highest similarity (approximately $80 \%$ ) was between October and November (Figures 3 and $4 \mathrm{~g}$ ).

Finally, the DGGE analysis of the bacteria revealed a number of bands ranging from 43 to 52 . The cluster analysis revealed a separation between July-August (that were very similar, i.e. $>90 \%$ ) and the other months (that displayed lower similarity 
(a) DGGE $1651.93 \%$

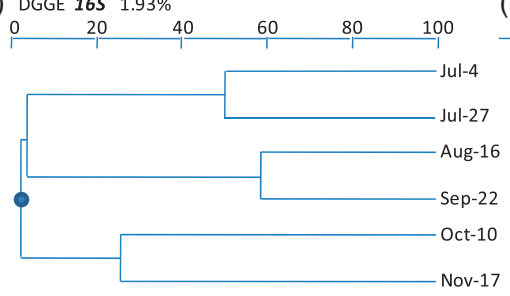

(c)

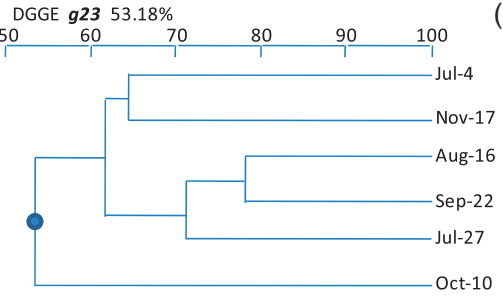

(e) DGGE psbD $17.85 \%$

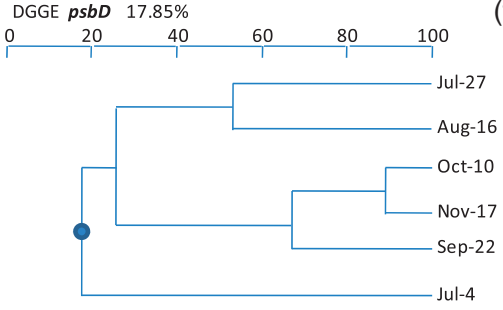

(g) DGGE avs $10.05 \%$

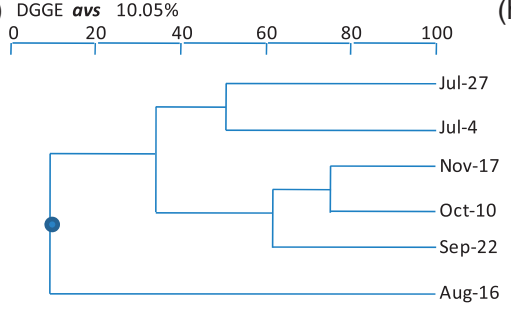

(b) DGGE g20 $43.38 \%$

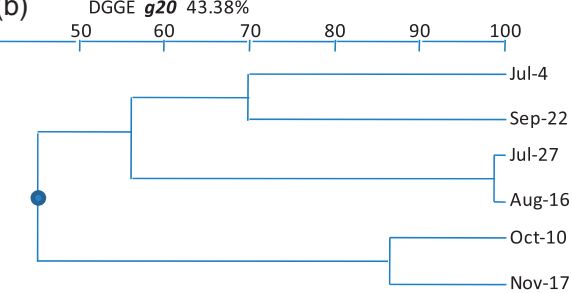

(d)

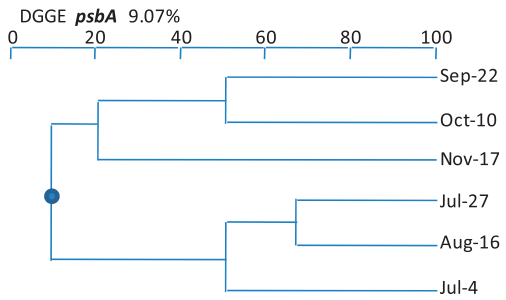

(f)

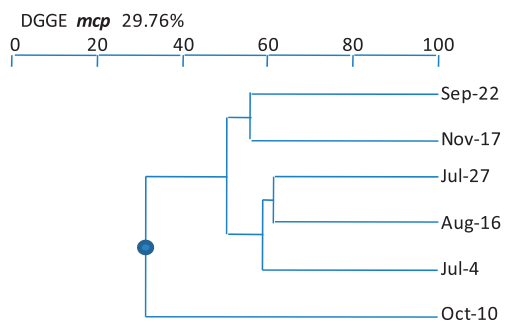

(h)

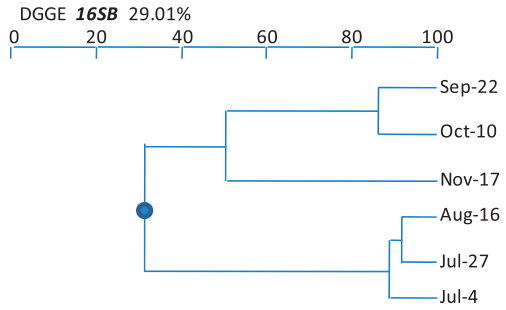

Figure 4. Cluster analyses of the different viral and cellular gene populations. The dendograms are constructed from a binary matrix of similarity values, using a distance calculation algorithm based on the absence/presence and relative fluorescence of the bands.

between them, especially between September-October and November, i.e. around $50 \%$, see Figure 4h).

\subsection{Relationships between variables}

The relationships between all the parameters were calculated using the Spearman's correlation. Typically, positive relationships were found between heterotrophic bacteria and the calanoid E. gracilis $(r=0.94, n=6)$, and between phytoplankton and Daphnia 


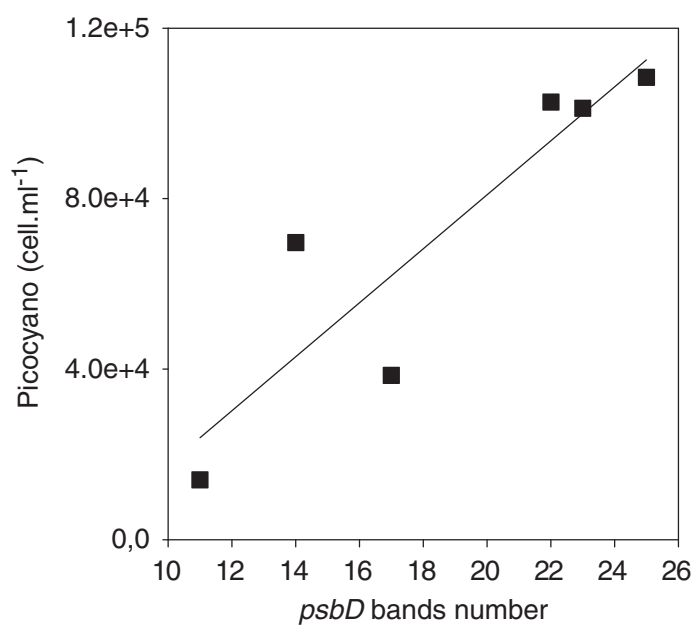

Figure 5. An example of relationships between variables: the number of the $p s b D$ number of bands in PCR-DGGE and the picocyanobacterial abundance.

$(r=0.89, n=6)$ and $\mathrm{O}_{2}(r=0.94, n=6)$ while there was a negative relationship between the picocyanobacterial abundance and $\mathrm{SiO}_{2}(r=-0.88, n=6)$. There were other relationships but with lower significance. Heterotrophic bacterial abundance was significantly correlated to crysophyceae (Dinobryon spp) and $\mathrm{NH}_{4}(r=0.79$ and $0.88, n=6)$. It was also found that the VLP2 had a significant positive correlation with chlorophyll $a(r=0.83$, $n=6)$, cyanobacterial abundance $(r=0.81, n=6)$ and $\mathrm{NH}_{4}(r=0.80)$ and VLP1 had a significant positive correlation only with bacterial abundance $(r=0.76, n=6)$. In addition to these biological factors, the VLPs were found to be negatively related to $\mathrm{N}-\mathrm{NO}_{3}$ $(r=-0.82, n=6)$ and $\mathrm{SiO}_{2}(r=-0.75, n=6)$. The bacterial abundance had only a significant positive correlation with Ptot and Ntot while we did not find any significant relationship between the picocyanobacteria and the other biological or chemical factors. Phytoplankton abundance correlated with diatoms and this group correlated with Ptot, cladocerans and the number of PFGE bands. Cyanopodoviruses correlated with PFGE bands while cyanomyoviruses did not correlate with any biological variable.

For the gene band numbers, there was no significant relationship between any variable and the $g 20$ specific richness. However, we did observe significant relationships between $m c p$ and heterotrophic bacterial abundance $(r=-0.85, n=6)$ and between $g 23$ and Ntot $(r=-0.83, n=6)$. There were also significant relationships between $p s b D$ and picocyanobacterial abundance $(r=0.90, n=6$, Figure 5$)$, chlorophyceae $(r=0.86, n=6)$ and $\mathrm{SiO}_{2}(r=-0.90, n=6) . p s b A$ presented significant relationships with crysophyceae $(r=0.91, n=6)$, cryptophyceae $(r=0.97, n=6)$ and xanthophyceae $(r=-0.83, n=6)$.

\section{Discussion}

Lake Geneva, despite being the largest lake in Western Europe, has been poorly investigated in terms of viral ecology. To the best of our knowledge, only three studies have been conducted so far [29-31] and none of them encompassed the viral 'diversity'. 
Here, we could propose for the first time a survey over a short period of time ( 5 months) of viral group relative diversity and abundances in relation to the main environmental parameters. This study is particularly original since (i) six different signature genes were used to assess viral richness at the same time in parallel with PFGE and PCR-DGGE also applied to cyanobacteria and bacteria, (ii) cyanophages were enumerated using real-time PCR, (iii) cyanopodoviruses were enumerated using quantitative PCR.

As already reported elsewhere, two groups of viruses could be discriminated using flow cytometry and VLP1 was correlated to bacterial abundances while VLP2 was correlated with both picocyanobacterial abundance and chlorophyll $a$. We already observed such relationships in peri-alpine lakes [30] suggesting that VLP1 and VLP2 could be more associated with bacteriophages and cyanophages, respectively. To go further, we used the flow cytometric sorting capacity of our instrument at different occasions and the different primers used in this study were tested on the sorted groups with/without reconcentrating them. We could not, however, confirm that algal and cyanobacterial virus primers only amplify viruses sorted from the VLP2 signature. On the other hand, in most cases AVS and $m c p$ primers were $(90 \%)$ unable to amplify both VLP1 and VLP2, suggesting that algal viruses were either not sufficiently concentrated or that they were elsewhere (i.e. not in these FCM signatures, see [29]). In contrast, VLP1 and VLP2 responded often positively to CPS4/5 but more to VLP2 than to VLP1, supporting the previous assumption that VLP2 could be mainly related to cyanophages [31].

Unlike the $16 \mathrm{~S}$ rRNA gene which is used as a universal marker for assessing bacterial diversity, only partial virus diversity can be assessed using smaller taxonomic group specific markers that are available [42]. In our study, we used and targeted genes which encode the portal protein, the DNA polymerase, the major capsid protein and photosynthetic proteins, providing for the first time in an aquatic ecosystem a synoptic view of phytoplanktonic viral richness and structure evolution. Although we did not cut bands or use PCR products for cloning/sequencing to verify the identity of bands, the simple use of the fingerprinting methods (i.e. PFGE and DGGE) was very useful to assess viral richness in a lake where such methods have not been applied so far.

At first sight, PFGE analysis suggested that total viral richness increased along summer until early fall. The increase of the number of bands in the $30-100 \mathrm{~kb}$ range from September to November was accompanied by the increase of the concentration of heterotrophic bacteria while it was the picocyanobacteria for the $150-200 \mathrm{~kb}$. Such a result could be expected since such size genome ranges suit what has been reported elsewhere for both bacteriophages and cyanophages [43]. Also a tight coupling could be observed between $16 \mathrm{~S}$ rRNA PCR-DGGE and PFGE $(r=0.72)$ suggesting co-variation between virus and prokaryotic host diversity in Lake Geneva. Such data indicating that phage and bacteria may co-vary remain, however, scarce and almost no data exist for freshwaters [44]. The phage community was prevalent in all the samples with five core genome sizes being common in all the samples $(35,38,48,75,95 \mathrm{~kb})$. It is noteworthy that the $95 \mathrm{~kb}$ band could also be a cyanophage [45]. The bands possibly representing cyanophage genomes [46], i.e. the $160,170,190$ and $200 \mathrm{~kb}$ were present in all the samples. Finally, the 195, 250, 270290,310 and $320 \mathrm{~kb}$ size populations appeared from September to November and the presence of the 200, 230 and $300 \mathrm{~kb}$ were clearly linked to the higher abundance of some eukaryotic algae at fall. Indeed, these bands were either less prominent or absent in July and August when the abundance of the eukaryotic algae was lower. Viral populations with genome sizes above $300 \mathrm{~kb}$ (likely algal viruses) were less visible either due to lower abundance or loss during the ultrafiltration process. It appears clear that the variability 
observed in the total viral community structure was likely a result of the net production and loss of viral populations, which was directly influenced by host abundance and susceptibility $[15,47]$. In turn, changes in the viral community structure could strongly influence shifts in the prokaryotic and eukaryotic communities through the interaction of the viruses with their potential hosts.

The PCR-DGGE of the employed signature genes revealed marked seasonal differences. Indeed, we could observe that the structure changed in various ways, in July, August and sometimes September clustering together or at least revealing a clear separation with the following fall months (e.g. for the picocyanobacteria, the cyanomyoviruses, $p s b A$ ). For some other genes, a transition could also be marked with a single month, e.g. early July for $p s b D$, August for AVS and October for $g 23$ and $m c p$. Thus, there were clear differences in the seasonal patterns of the genes investigated and such changes in the structure of the different signature genes were likely to be attributed to the changes in host structure. The detailed analysis of the phytoplankton database revealed that important changes occurred in the abundance, dynamics and diversity of the phytoplankton but it was not possible from these data to discriminate between bottom up (light, nutrients, etc.) and top down effects (including possible viral lysis effect but also and merely zooplanktonic grazing). Though no association could be observed between the Shannon diversity index and any of the genes examined, a significant and negative relationship was recorded between $m c p$ and the Brettum index applied to the phytoplankton ( $r=0.65, n=6$, not shown), suggesting, as expected, a tight coupling between phycoDNA viruses and eukaryotic algal hosts. The difficulty in presenting obvious and clear associations between viruses and hosts in general can be associated with sampling strategies. In our case, sampling approximately every month over a (too) short period of time (e.g. 5 months) and from an integrated water volume $(0-20 \mathrm{~m})$ could have masked relationships between viruses and hosts both in terms of abundance and structure [48].

Among targeted viral genes, $p s b D$ seem to be an excellent marker, providing the highest number of bands and discriminating early summer, end of summer and fall samples. Firstly, this result reinforces the idea that $p s b D$ may be widely distributed in cyanophage isolates and through a diversity of environments [45,49-51]. Secondly, our results could suggest that $p s b D$ is much more diverse than previously reported and could be found in many groups affecting the cyanobacteria of Lake Geneva. This is supported by the observation that the diversity in $p s b D$ was significantly and positively correlated with picocyanobacterial abundance reinforcing the previous assumption and the tight coupling already reported in the marine field between this gene and picocyanobacteria. In addition, we did not detect any clear link with other (colonial and/or filamentous) cyanobacteria. On the other hand, we found that $p s b D$ diversity was linked to chlorophyceae and $p s b A$ also displayed a significant correlation with both cryptophyceae and crysophyceae. Even though no proof of the existence of such photosynthetic genes has been provided yet in eukaryotic algal viruses, we believe that such transfers may not be impossible. A pertinent question here is: Could viral photosynthetic genes be exchanged not only between phages of Synechococcus but also with viruses of green algae? Of course, such relationships have to be interpreted with caution since they could just be indirect. The finding that viruses carry such photosynthetic genes could finally suggest that they may also be directly responsible for a significant proportion of carbon fixation in Lake Geneva.

Another important assay was the qPCR which allowed us to assess the abundance (i.e. gene copies) of both cyanomyoviruses and cyanopodoviruses. Until now, only a couple of studies have provided such estimates (see below). Total cyanophages were relatively 
abundant but they did not represent a substantial proportion of the total viral community (largely $<1 \%$ ). Their variations with time suggested possible interactions with some hosts but this could also be a response to some environmental parameters (see below). The cyanopodoviruses could be present in similar or sometimes even higher abundance than cyanomyoviruses. This is in contrast to earlier reports that reported the dominance of cyanomyoviruses over cyanopodoviruses [16,52]. It is noteworthy however that this previous study was conducted in a marine environment and it is assumed that in marine environments, genetic exchanges occur among viruses infecting more distantly related hosts [53]. It is possible that cyanopodoviruses are present with equal significance as cyanomyoviruses in lacustrine environments and this could be easily explained through the highest diversity of cyanobacteria present in freshwaters. Also, the previous studies that reported on the higher abundance of cyanomyoviruses used degenerate primers for the detection of the $g 20$ gene [53] but reported to be specific for marine cyanomyoviruses. Hence it is important to re-evaluate the use of such primers specific for marine cyanomyoviruses in studies pertaining to lacustrine environments. Besides, the burst size of the cyanopodoviruses could be higher than] for the cyanomyoviruses explaining higher abundances for this T7-like cyanophage community. Our estimates of cyanomyoviruses could only be compared to the two available studies existing so far: that of [54] for Lake Erie and that of [38] for a coastal area in Norwegian waters. Our estimates were clearly lower than those found in Lake Erie but comparable and even slightly higher than that of Raunefjorden. Finally, the cyanomyoviral density displayed significant positive correlations with $\mathrm{NO}_{3}$ and $\mathrm{PO}_{4}$ whereas the cyanopodovirus showed a negative relationship with the diatoms, dinoflagellates and PFGE banding patterns. This could suggest very different dynamics, role and influence for these two groups of cyanophages but further investigations are needed to determine the time scales of maximal abundances of these cyanophages and their ecological role in Lake Geneva.

\section{Conclusion}

In the assessment of viral richness and dynamics in Lake Geneva, PCR-DGGE proved to be very useful and provided a lot of information on the potential diversity of viruses infecting phytoplankton and seasonality of the main groups in relation to possible hosts and environmental parameters. Though our data clearly suggested that viral diversity changed over the period of study, revealing a marked transition for many groups between summer and fall, the sampling strategy adopted here could also be responsible for the difficulty encountered in interpreting some relationships between the different parameters. Obtaining, in such an ecosystem survey, a longer time series with a better sampling strategy (i.e. at discrete depths and with a higher frequency) is thus critical to highlight more precisely both diversity and algal-virus relationships. Finally, we are also aware of the limitations of such fingerprinting methods and, in the future, PCR assays using specific primers to follow the dynamics of abundances of specific viral groups infecting key phytoplanktonic groups or species such as diatoms, chlorophyceae or zygophyceae, together with pyrosequencing and metagenomics will prove invaluable in understanding of the diversity and importance of viruses in Lake Geneva. This was recently proposed for a neighbouring lake (i.e. Lake Bourget) to Lake Geneva [55]. 


\section{Acknowledgements}

The authors are grateful to the Director of the National Institute of Oceanography, Goa and Scientist-in charge, NIO, RC, Kochi for their moral support and the financial support provided by the Department Ecologie des Forets, Prairies et milieu Aquatiques from Institut National de la Recherche Agronomique (INRA). We are grateful to Jean-Christophe Hustache and Pascal Chifflet who helped with sampling, and Frédéric Rimet and Leslie Lainé for phytoplankton and zooplankton analyses, respectively. We also want to thank Lyria Berdjeb for her critical reading of a former version of the manuscript. For PA this is NIO contribution number 5245. XZ and was supported by Région Rhône-Alpes (through a PhD grant).

\section{References}

[1] F. Partensky, W.R. Hess, and D. Vaulot, Prochlorococcus, a marine photosynthetic prokaryote of global significance, Microbiol. Mol. Biol. Rev. 63 (1999), pp. 106-127.

[2] C. Callieri, Single cells and microcolonies of freshwater picocyanobacteria: A common ecology, J. Limnol. 69 (2010), pp. 257-277.

[3] K.E. Wommack and R.R. Colwell, Virioplankton: Viruses in aquatic ecosystems, Microbiol. Mol. Biol. Rev. 64 (2000), pp. 69-114.

[4] L. Poorvin, J.M. Rinta-Kanto, D.A. Hutchins, and S.W. Wilhelm, Viral release of iron and its bioavailability to marine plankton, Limnol. Oceanogr. 49 (2004), pp. 1734-1741.

[5] M. Middelboe and N.O.G. Jørgensen, Viral lysis of bacteria: An important source of dissolved amino acids and cell wall compounds, J. Mar. Biol. Assoc. UK 86 (2006), pp. 605-612.

[6] D.L. Lindell, M.B. Sullivan, Z.I. Johnson, A. Tolonen, F. Rohwer, and S.W. Chisholm, Transfer of photosynthesis genes to and from Prochlorococcus viruses, PNAS 101 (2004), pp. 11013-11018.

[7] S.W. Wilhelm and A.R. Matteson, Freshwater and marine virioplankton: A brief overview of commonalities and differences, Fresh. Biol. 53 (2008), pp. 1076-1089.

[8] M.G.Weinbauer, O. Bonilla-Findji, A.M. Chan, M. Agis, J.R. Dolan, S.M. Short, K. Šimek, S.W. Wilhelm and C.A. Suttle, Synechococcus growth in the ocean may depend on the lysis of heterotrophic bacteria, J. Plank. Res. 33 (2011), pp. 1465-1476.

[9] C.A. Suttle and A.M. Chan, Dynamics and distribution of cyanophages and their effect on marine Synechococcus spp., Appl. Environ. Microbiol. 60 (1994), pp. 3167-3174.

[10] M.B. Sullivan, J.B. Waterbury, and S.W. Chisholm, Cyanophages infecting the oceanic cyanobacterium, Prochlorococcus, Nature 424 (2003), pp. 1047-1051.

[11] F. Chen, K. Wang, S.J. Huang, H.Y. Cai, M.L. Zhao, N.Z. Jiao, and E. Wommack, Diverse and dynamic populations of cyanobacterial podoviruses in the Chesapeake Bay unveiled through DNA polymerase gene sequences, Environ. Microbiol. 11 (2009), pp. 2884-2892.

[12] M. Middelboe, S. Jacquet, and M.G. Weinbauer, Viruses in freshwater ecosystems: An introduction to the exploration of viruses in new habitats, Fresh. Biol. 53 (2008), pp. 1069-1075.

[13] S. Jacquet, T. Miki, R. Nobel, P. Peduzzi, and S.W. Wilhelm, Viruses in aquatic ecosystems: Important advancements of the last 20 years and prospects for the future in the field of microbial oceanography and limnology, Adv. Oceanogr. Limnol. 1 (2010), pp. 97-141.

[14] C.A. Suttle, Marine viruses-major players in the global ecosystem, Nat. Rev. Microbiol. 5 (2007), pp. 801-812.

[15] S.M. Short, The ecology of viruses that infect eukaryotic algae, Environ. Microbiol. 14 (2012), pp. 2253-2271.

[16] M.B. Sullivan, M.C. Coleman, V. Quinlivan, J.E. Rosenkrantz, A.S. DeFrancesco, G. Tan, R. Fu, J.A. Lee, J.B. Waterbury, J.P. Bielawski, and S.W. Chisholm, Portal protein diversity and phage ecology, Environ. Microbiol. 10 (2008), pp. 2810-2823.

[17] F. Rohwer and R. Edwards, The phage proteomic tree: A genome-based taxonomy for phage, J. Bacteriol. 184 (2002), pp. 4529-4535. 
[18] Y. Zhong, F. Chen, S.W. Wilhelm, L. Poorvin, and R.E. Hodson, Phylogenetic diversity of marine cyanophage isolates and natural virus communities as revealed by sequences of viral capsid assembly protein gene g20, Appl. Environ. Microbiol. 68 (2002), pp. 1576-1584.

[19] C.M. Frederickson, S.M. Short, and C.A. Suttle, The physical environment affects cyanophage communities in British Columbia Inlets, Microb. Ecol. 46 (2003), pp. 348-357.

[20] U. Dorigo, S. Jacquet, and J.F. Humbert, Cyanophage diversity, inferred from g20 gene analyses, in the largest natural lake in France, Lake Bourget, Appl. Environ. Microbiol. 70 (2004), pp. 1017-1022.

[21] S.W. Wilhelm, M.J. Carberry, M.L. Eldridge, L. Poorvin, M.A. Saxton, and M.A. Doblin, Marine and freshwater cyanophages in a Laurentian Great Lake: Evidence from infectivity assays and molecular analyses of g20 genes, Appl. Environ. Microbiol. 72 (2006), pp. 4957-4963.

[22] T.C.E. Chow and J.A. Fuhrman, Seasonality and monthly dynamics of marine myovirus communities, Environ. Microbiol. 14 (2012), pp. 2171-2183.

[23] M.R.J. Clokie, A.D. Millard, A.V. Letarov, and S. Heaphy, Phages in nature, Bacteriophage 1 (2011), pp. 31-45.

[24] K. Wang and F. Chen, Prevalence of highly host-specific cyanophages in the estuarine environment, Environ. Microbiol. 10 (2008), pp. 300-312.

[25] C. Chénard and C.A. Suttle, Phylogenetic diversity of cyanophage photosynthetic genes (psbA) in marine and fresh waters, Appl. Environ. Microbiol. 74 (2008), pp. 5317-5324.

[26] S.M. Short and C.A. Suttle, Sequence analysis of marine virus communities reveals that groups of related algal viruses are widely distributed in nature, Appl. Environ. Microbiol. 68 (2002), pp. 1290-1296.

[27] S.M. Short and C.M. Short, Diversity of algal viruses in various North American freshwater environments, Aquat. Microb. Ecol. 51 (2008), pp. 13-21.

[28] J.B. Larsen, A. Larsen, G. Bratbak, and R.A. Sandaa, Phylogenetic analysis of members of the Phycodnaviridae virus family, using amplified fragments of the major capsid protein gene, Appl. Environ. Microbiol. 74 (2008), pp. 3048-3057.

[29] S. Duhamel, I. Domaizon, S. Personnic, and S. Jacquet, Assessing the microbial community dynamics and the role of bacteriophages in bacterial mortality in Lake Geneva, Wat. Sci. 19 (2006), pp. 115-126.

[30] S. Personnic, I. Domaizon, U. Dorigo, L. Berdjeb, and S. Jacquet, Seasonal and spatial variability of virio-, bacterio-, and picophytoplanktonic abundances in three peri-alpine lakes, Hydrobiol. 627 (2009a), pp. 99-116.

[31] S. Personnic, I. Domaizon, T. Sime-Ngando, and S. Jacquet, Seasonal variations of microbial abundances and virus-versus flagellate-induced mortality of picoplankton in three peri-alpine lakes, J. Plank. Res. 31 (2009b), pp. 1161-1177.

[32] O. Anneville, C. Kaiblinger, R.D. Tadonléké, J.C. Druart, and M.T. Dokulil, Contribution of long-term monitoring to the European Water Framework Directive implementation. Proceedings of Taal 2007: The 12th World Lake Conference (2008), M. Sengupta and R. Dalwani (Eds.), pp. 1122-1131.

[33] J.P. Pelletier and A. Orand, Appareil de prélèvement d'un échantillon dans un fluide, INRA Patent number 197876.08579.

[34] H. Von Utermöhl, Neue Wege in der quantitativen Erfassung des Planktons. (Mit besondere Beriicksichtigung des Ultraplanktons), Verh. Int. Verein. Theor. Angew. Limnol. 5 (1931), pp. 567-595.

[35] D. Vaulot, CYTOPC: Processing software for flow cytometric data, Signal Noise 2 (1989), p. 8.

[36] S. Jacquet, X. Zhong, A. Parvathi, and A.S. Pradeep Ram, First report of a cyanophage infecting the cyanobacterium, Arthrospira platensis, J. Appl. Phycol. (2012), DOI: 10.1007/s10811-0129853-x.

[37] J. Colombet, M. Charpin, A. Robin, C. Portelli, C. Amblard, H.M. Cauchie, and T. SimeNgando, Seasonal depth-related gradients in virioplankton: Standing stocks and relationships with microbial communities in Lake Pavin (France), Microb. Ecol. 58 (2009), pp. 728-736. 
[38] R.A. Sandaa and A. Larsen, Seasonal variation in virus-host populations in Norwegian coastal waters: Focusing on the cyanophage community infecting marine Synechococcus spp., Appl. Environ. Microbiol. 72 (2006), pp. 4610-4618.

[39] Ø. Hammer, D.A.T. Harper, and P.D. Ryan, PAST: Paleontological statistics software package for education and data analysis, Palaeontologia Electronica 4 (2001), p. 9.

[40] R.D. Tadonléké, Evidence of warming effects on phytoplankton productivity rates and their dependence on eutrophication status, Limnol. Oceanogr. 55 (2010), pp. 973-982.

[41] M. Cellamare, A. Rolland, and S. Jacquet, Flow cytometric sorting of freshwater phytoplankton, J. Applied Phycol. 22 (2010), pp. 87-100.

[42] S.M. Short, F. Chen, and S.W. Wilhelm, The construction and analysis of marker gene libraries, Manual of Aquatic Viral Ecology 9 (2010), pp. 82-91.

[43] R.A. Sandaa. Viral pool, environmental. In: Encyclopedia in Microbiology, third edition, Ed: M. Schaechter, Section: Environmental Microbiology and Ecology. 2009. Elsevier Ltd. pp. 553-567.

[44] D. Lymer, E.S. Lindstrom, and K. Vrede, Variable importance of viral-induced bacterial mortality along gradients of trophic status and humic content in lakes, Fresh. Biol. 53 (2008), pp. 1101-1113.

[45] A. Millard, M.R.J. Clokie, D.A. Shub, and N.H. Mann, Genetic organization of psbAD region in phages infecting marine Synechococcus strains, PNAS 101 (2004), pp. 11007-11012.

[46] N.H. Mann, A. Cook, A. Millard, S. Bailey, and M. Clokie, Bacterial photosynthesis genes in a virus, Nature 424 (2003), p. 741.

[47] M. Breitbart, Marine viruses: Truth or dare, Annu. Rev. Mar. Sci. 4 (2012), pp. 425-448.

[48] L. Berdjeb, T. Pollet, I. Domaizon, and S. Jacquet, Effects of grazers and viruses on bacterial community structure and production in two contrasting trophic lakes, BMC Microbiol. 11 (2011), p. 88 .

[49] A.D. Millard, K. Zwirglmaier, M.J. Downey, N.H. Mann, and D.L. Scanlan, Comparative genomics of marine cyanomyoviruses reveals the widespread occurrence of Synechococcus host genes localized to a hyperplastic region: Implications for mechanisms of cyanophage evolution, Environ. Microbiol. 11 (2009), pp. 2370-2387.

[50] I. Sharon, S. Tzahor, S. Williamson, M. Shmoish, D. Man-Aharonovich, D. B. Rusch, S.Yooseph, G. Zeidner, S.S. Golden, S. R. Mackey, N. Adir, U. Weingart, D. Horn, J. C. Venter, Y. Mandel-Gutfreund and O. Béjà, Viral photosynthetic reaction centre genes and transcripts in the marine environment, ISME J. 1 (2007), pp. 492-501.

[51] M.B. Sullivan, D.L. Lindell, J.A. Lee, L. Thompson, J.P. Bielawski, and S.W. Chisholm, Prevalence and evolution of core photosystem II genes in marine cyanobacterial viruses and their hosts, PLoS Biol. 4 (2006), p. e234.

[52] J.B. Waterbury and F.W. Valois, Resistance to co-occurring phages enables marine Synechococcus communities to coexist with cyanophages abundant in seawater, Appl. Environ. Microbiol. 59 (1993), pp. 3393-3399.

[53] N.J. Fuller, W.H. Wilson, I.R. Joint, and N.H. Mann, Occurrence of a sequence in marine cyanophages similar to that of T4 g20 and its application to PCR based detection and quantification techniques, Appl. Environ. Microbiol. 64 (1998), pp. 2051-2060.

[54] A.R. Matteson, S.N. Loar, R.A. Bourbonnière, and S.W. Wilhelm, Molecular enumeration of an ecologically important cyanophage in a Lauretian great lake, Appl. Environ. Microbiol. 77 (2011), pp. 6772-6779.

[55] S. Roux, F. Enault, A. Robin, V. Ravet, S. Personnic, S. Theil, J. Colombet, T. Sime-Ngando, and D. Debroas, Assessing the diversity and specificity of two freshwater viral communities through metagenomics, PLOS ONE 7 (2012), p. e33641. 